\title{
"Água mole em pedra dura, tanto bate até que fura": o caminho das águas na catalisação social no Brasil Colonial
}

\author{
Cláudia Regina Plens* \\ Vagner Cavalheiro Porto**
}

\begin{abstract}
PLENS, C.R.; PORTO, V.C. "Água mole em pedra dura, tanto bate até que fura”: o caminho das águas na catalisação social no Brasil Colonial. $R$. Museu Arq. Etn., 26: 95-114, 2016.
\end{abstract}

Resumo: Entre serras, montanhas e uma rede de bacias hidrográficas, Guarulhos possui caminhos naturais que permitiram a movimentação da colonização europeia para a exploração humana e de seus recursos minerais. Ademais das rotas naturais, remanescentes arqueológicos da mineração de Guarulhos, SP, datados de acordo com dados históricos a partir de 1590, indicam um grande empenho por meio de trabalho humano, sobretudo indígena, na construção de reservatórios e canais como objetivo de se explorar o ouro. A região onde se encontra atualmente o município de Guarulhos é um importante ponto para se compreender as primeiras formas de contato durante a colonização portuguesa e sua interação com grupos indígenas e suas estratégias para expansão territorial. O objetivo deste artigo é apontar como o empreendimento de mineração vem implicando no comportamento de diversos segmentos da sociedade guarulhense, desde o início deste ciclo econômico até os dias atuais.

Palavras-chaves: Arqueologia do Colonialismo; mineração; mão de obra escrava indígena; Arqueologia do Movimento; Arqueologia do sagrado.

"Indian voices largely are silent, but the artifacts crafted by the natives are obvious and extant. Their hands made the bricks that formed the adobe. Their arms lifted the whitewash brushes to the walls and brought the wood." (Silliman, 2010: 48-9).

\section{Introdução}

A descoberta de ouro e água em abundância em terras onde hoje se localiza Guarulhos-SP atraiu o olhar do colonizador português e levou a uma dramática mudança social e na paisagem local. Embora a riqueza natural de recurso

(*) Arqueóloga, Professora do Departamento de História da UNIFESP.

$\left.{ }^{(* *}\right)$ Arqueólogo, Professor do Museu de Arqueologia e Etnologia da Universidade de São Paulo. aquático na localidade, a necessidade de lavrar o ouro levou a procura do manejo da paisagem para a captação e represamento de recursos aquáticos de nascentes da Serra da Cantareira, reconfigurando os percursos e permitindo nova rede de contatos entre a sociedade de um dos primeiros vilarejos do Brasil colonial do final do século XVI.

O impacto ambiental causado pela mineração de Guarulhos foi alto, necessitou de cortes em montanhas, cortes em pedras, execução de curvas em leitos de rios e riachos, represamento 
“Água mole em pedra dura, tanto bate até que fura": o caminho das águas na catalisação social no Brasil Colonial

R. Museu Arq. Etn., 26: 95-114, 2016

de águas, construção de dutos, "aquedutos", galerias e canais para lavagem em meio à mata. Ademais, tratou-se de impactos permanentes, pois as ruínas e as transformações paisagísticas estão presentes até os dias atuais.

Contudo, o ouro e a água não foram apenas transformadores ambientais e paisagísticos, mas, sobretudo, catalisadores sociais. Grupos indígenas que se encontravam nas adjacências formaram a base da mão de obra do empreendimento minerador.

Dessa forma, o território atualmente ocupado por Guarulhos, Mairiporã e Nazaré Paulista conjugou três fatores que, intrinsicamente associados, tornaram essa região ideal para a exploração aurífera: disponibilidade de mão de obra de grupos indígenas que viviam na região - escrava -, matéria-prima, o ouro, e a grande quantidade de recursos aquáticos disponiveis pela configuração espacial da localidade.

Embora a presença indígena em Guarulhos seja de suma importância para a constituição histórica dos primeiros quatrocentos anos de colonização europeia, a identidade e a localização de aldeias e aldeamentos são controversos (vide Vilardaga e Miranda), as diferentes nomenclaturas e terminologia para designar a cultura indígena era confusa inclusive na documentação escrita pela própria população contemporânea desses grupos.

Se os dados sobre identidade e localização dos assentamentos indígenas são vagos, sua importância para a história local é fato contundente, pois sabemos que o emprego de um grande número de trabalhadores indígenas foi necessário para o empreendimento minerador. Em contexto norte-americano, Silliman (2010: 33) reconhece problema semelhante e acredita que são válidos os esforços para entender a relação da ausência da materialidade indígena em contextos históricos cuja presença é conhecida.

Würst (1991: 15) chama a atenção para o fato de que nem sempre em contexto colonial a relação de espaço doméstico está separado do espaço de trabalho. Avançando nesta premissa, Silliman (2010: 38) aponta que na busca da materialidade cotidiana da presença indígena, a arqueologia tem pouco contribuído para compreender a presença indígena em contexto colonial, pois esses indivíduos geralmente utilizaram-se de objetos cotidianos diretamente em contexto de trabalho.

O objetivo deste artigo é analisar o processo de reconfiguração paisagística colonial e seu aspecto social da mineração de Guarulhos, para entender como e de que modo a mudança ambiental no período colonial a partir do processo minerador impactou a sociedade e a paisagem e reconfigurou culturalmente os modos de vida. Para tanto, partimos da cultura material em seu sentido mais amplo, paisagem cultural, edificações e caminhos para entender os meandros que forjaram as relações sociais no período que trataremos dentro dos temas de Arqueologia do Colonialismo e a Arqueologia do Movimento dentro da perspectiva da Arqueologia da Paisagem.

O tema da Arqueologia do Colonialismo envolve as relações de dominação intercultural, em que o colonizador incorpora a terra, população e recursos do colonizado para o gerenciamento da colônia com o objetivo final de exportar os recursos à metrópole (Jordan, 2009: 32). As formas de dominação são múltiplas e variáveis e podem ocorrer desde a dependência, onde os bens necessários são providos pelo colonizador, até por meio de rompimento, onde as ações impostas tornam impossivel o modo de vida do colonizado (Jordan, 2009: 35).

Migrações, deslocamentos de pessoas, objetos e ideias sempre foram constantes no mundo e foram vetores de promoção de culturas e convergências sociais. Foi, contudo, no encontro do Velho com o Novo mundo que o grande impacto cultural e biológico ocorreu de forma a afetar profundamente as sociedades de ambos os lados e reestruturando formas de vida desde suas práticas cotidianas, como na alimentação e saúde dos povos, até as formas de prática de poder e economia (Beaudry, 2013: 1).

Esse tema de encontro entre esses dois mundos tem sido uma incessante questão nas pesquisas arqueológicas. Não obstante, lacunas profundas ainda são encontradas na história desses grupos sociais que se encontraram e se reinventaram culturalmente.

Este trabalho volta ao tema do choque cultural entre o Velho e o Novo Mundo, na 
expectativa de se compreender os fatores que dispararam a reorganização das sociedades luso -brasileiras em contexto guarulhense.

\section{Contexto Ambiental}

A cadeia de montanhas recoberta pela Mata Atlântica que caracteriza o município de Guarulhos é conhecida como Serra da Cantareira, por meio da qual, em sua porção granítica principal, é irradiada uma rede de drenagem de rios e córregos (Ab'Saber, 2007: 77).

A bacia hidrográfica da região do Alto Tietê no território de Guarulhos compreende as bacias Jaguari, Cabuçu de Cima, Canal de Circunvalação, Baquirivu Guaçu. O próprio rio Tietê, que cruza diversos municípios do estado de São Paulo, é muito importante para Guarulhos. Tendo sua nascente localizada no município vizinho, Salesópolis, o rio Tietê corre em direção oeste e corta todo o município.

Da perspectiva geológica, o ambiente onde se encontra Guarulhos possui características singulares, sobretudo do ponto de vista mineralógico que, além do ouro, possui remanescentes de rochas depositadas por águas oceânicas em antigas eras geológicas (Pérez-Aguilar et al., 2012).

Essa área compreende dois afloramentos pertencentes ao segmento central da Faixa Ribeira (sendo que o primeiro é parcialmente recoberto pelo segundo), sendo eles: o grupo Serra do Itaberaba (Mesoproterozoico), de sequência meta-vulcanossedimentar e o São Roque (Neoproterozoico), representado por uma sequência meta-siliciclástica. Ambos os grupos são compostos por distintos corpos de granitoides sin - a pós-colisionais do período Neoproterozoico ao Cambriano (Pérez-Aguilar et al., 2012).

O afloramento do grupo Serra do Itaberaba inicialmente foi depositado em águas oceânicas, caracterizado pela presença de basalto do tipo N-MORB (normal mid ocean ridge basalt), tendo uma posterior evolução em ambiente de retroarco (Pérez-Aguilar et al., 2012).

Ainda de acordo com Pérez-Aguilar et al. (2012), os afloramentos possuem formações, lidas da base para o topo, da seguinte maneira:
- grupo Serra do Itaberaba:

1) Morro da Pedra Preta - composta por metabasitos do tipo N-MORB com presença de lavas almofadadas, rochas meta-vulcanoclásticas e metatufos com composições básicas a intermediárias e metatufitos;

2) Jardim Fortaleza - composta por xistos, xistos grafitosos, xistos ricos em sulfetos e xistos manganesiferos; subordinadamente, metabasitos, metatufos com composições básicas a intermediárias, metatufitos, rochas cálcio-silicáticas, formações ferríferas do tipo Algoma (BIFs) e turmalinitos;

3) Nhanguçu - composto por xistos ferro -manganesíferos e xistos cálcio-silicáticos com intercalações de pequenas lentes de metabasitos;

4) Pirucaia - composto por quartzitos, grãos de zircão, turmalina, rutilo e opacos com texturas reliquiares elásticas, e quartzo, mica xistos com sillimanita.

Essa composição foi responsável por extensas zonas de alteração clorítica (ZC1), cortadas por zonas restritas de alteração clorítica (ZC2), argílica e argílica avançada, cujas rochas são compostas por margarita \pm rutilo \pm coríndon ou por topázio \pm rutilo e levaram a processos mineralizantes de ouro (Pérez-Aguilar et al., 2012).

- grupo São Roque:

1) Pirapora do Bom Jesus (metabasitos e metassedimentos carbonáticos);

2) Morro Doce (meta-conglomerados polimíticos, meta-arcóseos e filitos);

3) Boturuna (arenitos e arenitos feldspáticos metamorfisados);

4) Estrada dos Romeiros (metassedimentos rítmicos) e

5) Jordanésia (metassedimentos rítmicos e metassedimentos grafitosos).

\section{A Arqueologia da Paisagem}

A materialidade da colonização é muitas vezes exígua, e uma primeira aproximação para o estudo do tema pode ocorrer por meio de discussão de macroconfiguração espacial de uma determinada área geográfica com o objetivo de 
“Água mole em pedra dura, tanto bate até que fura": o caminho das águas na catalisação social no Brasil Colonial

R. Museu Arq. Etn., 26: 95-114, 2016

entender a estruturação e articulação das áreas afetadas.

A literatura sobre a Arqueologia da Mineração explora temas diversos, mas, sobretudo ligados a temas de patrimônio, impactos ambientais, tecnológicos para a compreensão dos processos de extração e processamento, ou sociais para a compreensão sobre etnicidade, classe e gênero (Pearson, 1993; Pearson e McGowan, 2000). Contudo, a partir da Pesquisa de Inventário do Patrimônio Arqueológico de Guarulhos - PIPAG, o tema desta pesquisa se voltou para o modo como a reconfiguração de lugares singulares para a mineração de ouro culminou em uma transformação da rede de contatos e impactou a sociedade de modo a ressignificar seus valores socioculturais.

Trata-se, portanto, de uma leitura das modificações paisagísticas a partir do processo minerador implantado em Guarulhos. Embora a Arqueologia da Paisagem seja uma abordagem recorrente nas pesquisas arqueológicas, ela vem sendo aplicada de diferentes maneiras.

Com o surgimento da New Archaeology nos anos 1960, os arqueólogos americanistas reconheceram que as modificações nas paisagens antropogênicas implicam mais do que modificações físicas do ambiente; elas também implicam padrões ligados às "dimensões sociais e ideológicos" (Deetz, 1990: 2). Segundo Anschuetz, Wilshusen e Scheik (2001), a Arqueologia da Paisagem passa cada vez mais a considerar paisagens historicamente documentadas de forma mais holística, incluindo a mudança na organização do assentamento, a demografia e as relações sociopolíticas.

No caso do Reino Unido, a afirmação da Arqueologia da Paisagem assenta-se em uma tradição de abordagens ecológicas. Esse caminho fez com que a tônica da investigação envolvendo o tema paisagem recaísse sobre o estudo do meio (Orejas, 1991: 200-1 apud Marcolin, 2013: 3). A análise do meio é feita em níveis e escalas diferentes, focando cada um dos seus aspectos diferenciadores: as características climáticas, a geomorfologia, a hidrografia, a vegetação e a fauna.

O estudo do meio enquanto recurso, estabelecido na absorção feita pelas comunidades, presente nas bacias de exploração e nos assentamentos, associa-se a esse filão de pesquisa. Essa postura confere um importante protagonismo à reconstituição dos paleoambientes, promovendo o desenvolvimento integrado das várias formas de análise arqueológica antes descritas, atualmente reunidas num âmbito próprio: a chamada Arqueologia Ambiental (Orejas, 1991: 207 apud Marcolin, 2015: 3).

Diferentemente do que ocorre no Reino Unido, na França, são as esferas da geografia e da história que competem para a afirmação da Arqueologia da Paisagem. Em meados dos anos 1960, Georges Bertrand abordou a paisagem como um problema de método, inspirandose no vocabulário corrente dos ecossistemas (geótopo, geofácies, geossistema, região natural, campo geográfico, zona) e que também atribuiu uma perspectiva histórica ao estudo dos geossistemas (combinando história ecológica e história social.

Atualmente, o contexto francês se desenvolve em torno de duas abordagens que se contrapõem: a abordagem morfológica, representada pela archéomorphologie, e a abordagem naturalista, representada pela géoarchéologie (Leveau, 2006: 9, 21 apud Marcolin, 2015: 3). A archéomorphologie parte do pressuposto de que a forma da paisagem resulta da estratificação dos sistemas de ocupação no tempo, sendo que tais sistemas refletem os vínculos estabelecidos com o meio envolvente.

O estudo morfológico é conduzido em várias escalas, articulando-se os contextos espaciais em função da problemática em análise. A géoarchéologie foca essencialmente na reconstituição dos paleoambientes, "integrando uma abordagem analítica, centrada nos componentes da paisagem, e uma abordagem dinâmica, que considera os processos intervenientes na sua formação" (Leveau, 2006: 14-5 apud Marcolin, 2013: 4). A abordagem analítica considera a paisagem como realidade sistêmica, que integra os componentes geológico, biológico e humano.

A partir dos anos 1990, o crescimento do uso de conceitos relacionados à paisagem foi muito rápido. Isso é sintomático de uma mudança significativa no pensamento arqueológico sobre paisagens. Dentro dessa análise contínua 
das relações entre natureza e cultura, observando como as comunidades transformam espaços físicos em lugares significativos, as abordagens da paisagem apresentadas em compêndios recentes (e.g., Knapp e Ashmore, 1999; Crumley e Marquardt, 1987; Carmichael et al., 1994; Feld e Basso, 1996; Fisher e Thurston, 1999; Hirsch, O'Hanlon, 1995; Ucko, Layton, 1999) estabelecem quadros para a construção de uma arqueologia mais sintética de "lugar" (Anschuetz, Wilshushen, Scheik, 2001: 159).

$\mathrm{Na}$ atualidade, os lugares, assim como as paisagens, passaram a ser entendidos como significativos, adjetivados de várias maneiras (e.g. sagrados, perigosos, tradicionais, culturais) e estudados em termos de suas biografias, significados metafóricos e metonímicos, políticas, lógicas, redes, transformações e persistências (Whitridge, 2004; Stewart et al., 2004; Carroll et al., 2004; Brown, 2004; Bowser e Zedeño, 2009). Assim, pode-se entender uma "arqueologia do lugar" como:

Aquela que se concentra sobre os modos como as pessoas comunicam significado - tanto simbolicamente como através da ação - ao seu entorno físico e cultural em múltiplas escalas e sobre as formas materiais que estes significados adquirem (Bowser e Zedeño, 2009: 5). As pessoas criam lugares através de suas experiências com o meio (tangivel e intangivel), dando significados a eles e produzindo conhecimento sobre os mesmos. Os lugares têm uma dimensão individual e social, bem como agência para modelar e influenciar as ações das pessoas. Os lugares são irremediavelmente ligados à história e à memória das pessoas e, por isso, podem também assumir dimensões políticas e identitárias (Bowser, Zedeño 2009; Stewart, Strathern, 2003: 31).

Por fim, a ciência mais afim com a Arqueologia, a Antropologia, enquanto Antropologia Cultural, pesquisa a ideia de lugar como local de identidade e de contestação. Trabalhos com grupos indígenas mostram como as paisagens são importantes para as comunidades em termos de manutenção da memória e da tradição.
Susan Alcock (2002) tem trabalhado a questão da construção da identidade a partir da significação outorgada coletivamente a certos lugares. Desse modo, a lembrança compartilhada - a partir da memória social - permite a criação de imagens do passado e de desígnios para o futuro. No entanto, ao mesmo tempo em que é extremamente poderosa, a memória social é também fugidia. No livro Archeologies of the Greek Past (2002), Alcock, segundo Komikiari (2014), pretende alcançar esta fugida memória a partir de improvável documentação, a material, especificamente os monumentos e a paisagem.

Places, meanings, and memories are intertwined to create what some authors have termed a "sense of place. A sense of place rests upon, and reconstructs, a history of social engagement with the landscape, and is thus inextricably bound up with remembrance, and with time; its construction is tied into networks of associations and memories through a process Basso (1996: 107) calls interanimation. As humans create, modify, and move through a spatial milieu, the mediation between spatial experience and perception reflexively creates, legitimates, and reinforces social relationships and ideas (Alcock, 2003: 5).

Um último aspecto importante da discussão de paisagem na Arqueologia advém da chamada Arqueologia do Construído. Essa Arqueologia propõe a reflexão sobre algumas perguntas que de uma forma ou de outra perpassam pela proposta de discutir a relação do homem com a paisagem: como as formas construídas acomodam o comportamento humano e se adaptam às necessidades humanas? De que maneira se dá a acomodação de um grupo social a forma que ocupa? Quais são os possíveis significados da forma?

De acordo com Rapoport (1982), as formas construídas expressam e representam os aspectos da cultura. Esse autor sugere que as formas construídas são uma extensão do indivíduo, representam uma dimensão espacial do comportamento humano, com seus processos mentais e com sua fisicalidade própria do ser humano. 
"Água mole em pedra dura, tanto bate até que fura": o caminho das águas na catalisação social no Brasil Colonial

R. Museu Arq. Etn., 26: 95-114, 2016

Nessa relação, forma construída/ambiente construído, temos de considerar que os ambientes construídos são determinados por fatores histórico-culturais, fatores físicos e fatores teóricos. Carl (2000) discute essa questão ao relacionar a formação da cidade com a chamada topografia da praxis, na qual as descontinuidades da cidade seriam, na realidade, a continuidade de diferenças. Nesse sentido, as formas construídas se inserem num plano em que as diferenças fazem sentido e dão sentido a uma topografia, que se vista sem atenção poderia sugerir desníveis ou uma ausência de harmonia social. Em outras palavras, a morfologia da paisagem se dá a partir das continuidades e descontinuidades topográficas, econômicas, religiosas, políticas e sociais, enfim, culturais.

Da mesma maneira que a sociedade produz formas, as formas reproduzem a sociedade. É importante considerar os papéis da História e instituições sociais para a geração do ambiente construído reverberando numa relação de espaço-poder. Assim, partindo desse raciocínio, a forma construída não pode e não deve ser vista de modo estático, sem interação com a sociedade que a produziu. Cabe ao arqueólogo, com esse novo olhar, perceber a pulsação das formas construídas, entendendo-as a priori como componentes indissociáveis da própria natureza social do ser humano.

\section{Histórico}

De acordo com Miranda e Vilardaga, a presença indígena em Guarulhos em documentação histórica remonta ao início da colonização europeia, no século XVI, e segue presente, mesmo que progressivamente mais esparsa, até o século XIX, até sumir completamente dos documentos.

Nesse mesmo período de contato entre indígenas e europeus ocorreu um dos primeiros empreendimentos mineradores dos colonizadores no atual território de Guarulhos. Do mesmo modo que a presença indígena no território analisado, as principais trilhas que percorrem áreas de lavras de mineração teriam sido próximas aos atuais "ribeirões das Lavras e Tomé Gonçalves e dos córregos Tanque Grande e Guaraçau"
(Juliani et al., 1995: 6), além do rio Baquirivúguaçu, que compunham um amplo território permeado de lavras.

A partir do ciclo da mineração de ouro em Minas Gerais, no século XVIII, as propriedades paulistas passaram a ter propriedades rurais de diversas naturezas: desde pequenas chácaras e sítios, voltados à economia de subsistência e mercado local, até grandes fazendas centradas na produção de trigo, cana-de-açúcar e algodão, e na criação de gado que, além do mercado interno, abasteciam as regiões de mineração, possibilitando, também, o abastecimento e logística das rotas e pontos de paragem das tropas de muares que percorriam as rotas de São Paulo ao Rio de Janeiro e de São Paulo a Minas Gerais, e Brasil adentro.

Duas igrejas católicas mais antigas são importantes para compreendermos mais adiante os territórios de importância no período colonial, a Igreja Nossa Senhora do Bonsucesso e a atual matriz Nossa Senhora da Conceição. Embora ambas as igrejas tenham passado por reconstruções em lugares distintos da implantação original, ambas tiveram origem no período colonial, de acordo com dados históricos.

De acordo com dados de Vilardaga, embora a igreja Nossa Senhora da Conceição pareça ter sido formalmente construída em 1665 , há indícios que indicam que uma capela nessa localidade do mesmo nome da igreja já existia por volta de 1620 , quando um vilarejo ainda incipiente parece se formar ao redor desse território e já atrair romeiros de outras localidades em 1620.

Quanto à Igreja Nossa Senhora do Bonsucesso, embora o reconhecimento por parte da Igreja oficial, da existência da Festa do Bonsucesso e a data do ano de 1741 como o seu marco inicial, dados históricos apontam a presença da Capela do Bonsucesso, na sesmaria de Ururaí, na década de 1620, no entorno da Capela do Bonsucesso, em terras de Francisco Cubas. Essa igreja é ainda muito importante para a cultura local por sua festa que perdura até os dias atuais, realizando anualmente no mês de agosto celebrações no espaço do entorno da igreja.

$\mathrm{Na}$ atualidade, esses rituais são iniciados na primeira segunda-feira do mês de agosto, com a "carpição" do adro da igreja. Os demais finais 
de semana encerram novenas, missas, congadas, folias de reis, procissões e, ainda, um ritual de cura, a "Carpição", onde milhares de pessoas carregam um punhado de terra que, acreditam, se for colocada sobre uma parte enferma do corpo tem o poder de remediar o problema.

\section{Metodologia}

Para fim do inventário do projeto PIPAG, no que tange às ruínas de mineração do século XVI em Guarulhos, foram efetuadas prospecções arqueológicas de superfície, junto ao historiador Elton Soares de Oliveira, morador local. De modo geral, as ruínas se encontram atualmente em meio à mata e poucas na área urbanizada, como no caso do bairro Jardim Hanna.

Em princípio do projeto, o emprego de GPS para a localização das coordenadas das ruínas não obteve êxito, pois os erros de leitura eram bastante altos, fazendo com que as coordenadas fossem mapeadas em municípios adjacentes. Houve a tentativa do emprego de drone para fotografias e filmagens aéreas, porém, pelo fato de a grande maioria das ruínas estar em mata fechada, não conseguimos continuar com esse procedimento.

Recentemente, com o emprego de GPS Monterra e Montana (Garmin), o problema pôde ser contornado. Desta forma, as ruínas foram fotografadas e mapeadas de modo georreferenciado sistematicamente e fichas de inventário foram preenchidas com informações e características gerais.
Assim como se procedeu para o mapeamento das ruínas de mineração, antigos caminhos e rios foram mapeados de modo que pudéssemos empregar o estudo de rotas e movimentos sugerido por Earle (2006). Para o autor, rotas de movimento representam diferenças em formas de utilização, marco físico e construção. As rotas podem ter uma ou mais características, representando distância de trajetos, subsistência, mercado, rota de contatos, socialização, projeto de permanência, política e cerimônias. Mais do que isso, o grau de integração política e suas funções explicariam grande parte da variabilidade das rotas humanas (Earle, 2006: 255-60).

Topografia e hidrografia fazem parte das barreiras naturais a serem contornadas e transpostas pelas rotas construídas. Para tanto, Earle (2006: 261) sugere a utilização de variáveis de barreiras de topografia em extrema, moderada e baixa para início do mapeamento das barreiras.

Essa metodologia adaptada à área de pesquisa deste projeto, que relaciona caminhos, térreos e aquáticos, associados às barreiras topográfica e hidrográficas, nos permitirá uma leitura da paisagem colonial em seu aspecto mais marcante, a movimentação e trânsito social que lentamente crivaram no ambiente natural lugares de importância cultural.

\section{A Dutra no meio do caminho}

No início do projeto PIPAG, quando a equipe fazia o reconhecimento das adjacências da Igreja do Bonsucesso, conhecemos uma

\begin{tabular}{|c|c|c|c|c|c|}
\hline Rotas & Extensão espacial & Período de utilização & Volume & Construção & Funções \\
\hline Trilhas & Local & Cotidiano & Baixo & Baixo & Logístico \\
\hline $\begin{array}{c}\text { Cami- } \\
\text { nhos }\end{array}$ & Local e regional & Sazonal e periódico & Médio & Baixo & $\begin{array}{c}\text { Logístico e } \\
\text { cerimonial }\end{array}$ \\
\hline Estradas & $\begin{array}{c}\text { Regional e longa } \\
\text { distância }\end{array}$ & $\begin{array}{c}\text { Cotidiano, sazonal e } \\
\text { periódico }\end{array}$ & Alto & Alto & $\begin{array}{c}\text { Logístico, } \\
\text { cerimonial e } \\
\text { político }\end{array}$ \\
\hline
\end{tabular}

Tabela 1: Tipologia de rotas de movimentação adaptado de Earle (2006: 255). 
"Água mole em pedra dura, tanto bate até que fura": o caminho das águas na catalisação social no Brasil Colonial R. Museu Arq. Etn., 26: 95-114, 2016

senhora, Dona Neísa, vizinha da igreja, e que nos contou o que sabia acerca da Igreja. Ela nos relatou que, há mais de quarenta anos, quando da construção da casa do padre, haviam ossos e objetos "de índio" no terreno, que foram levados para a prefeitura. Ela teria presenciado o acontecimento, muito embora os funcionários da prefeitura e Arquivo Histórico atuais não tenham conhecimento do fato nem do material arqueológico.

Mais do que isso, Dona Neísa sabia que a igreja do Bonsucesso não era original, que ela teria sido em outra localidade antes do século XIX. Ainda que essa seja uma pergunta que sempre realizamos informalmente para a população, a maioria das pessoas desconhecia qualquer fato acerca de uma igreja anterior. Ela nos relatou que seu pai, um sitiante local, sempre tinha contado que a antiga igreja do Bonsucesso situava-se em uma área às margens da Rodovia Dutra, próximo ao quilômetro 209.

Ainda em prospecção de antigos caminhos próximo à localidade que pudesse explicar antigas rotas deparamo-nos com a Rua dos Jesuítas que, atualmente, começa e termina na Rodovia Dutra, no quilômetro 216 e apresenta uma configuração anterior à implantação dessa rodovia. Não conseguimos nenhum dado histórico sobre o assunto, seja por oralidade, ou por documen- tos, mas a configuração espacial e sua toponímia são notórias.

\section{As ruínas das Lavras de Ouro de Guarulhos}

As ruínas da mineração de ouro de Guarulhos são estruturas construídas para o gerenciamento de cursos d'águas, transpondo e contornando os relevos para a mineração das lavras de aluvião. São estruturas confeccionadas com pedras cortadas, com túneis escavados em rochas, trincheiras para o gerenciamento dos cursos d'água, trilhas como sistema de circulação humana, cavas, dutos com o objetivo de canalização d'água para a mineração de rios e riachos que descem da serra da Cantareira por meio do rio Tomé Gonçalves, ribeirão das Lavras, córrego Guaraçau, córrego Guavertuva, e ribeirão Tanque Grande.

Entre séries de relevos escavados e margens de rios corre água com alta pressão a partir de uma altitude de $1200-1000 \mathrm{~m}$, no ponto mais alto, e em $763 \mathrm{~m}$ de altura, o ponto mais baixo.

O mapeamento espacial das ruínas demonstra que o empreendimento de exploração de ouro se tratou de um sistema integrado. A partir das áreas de maior porte para a captação d'água, na zona mais ao norte, cuja área é ocu-

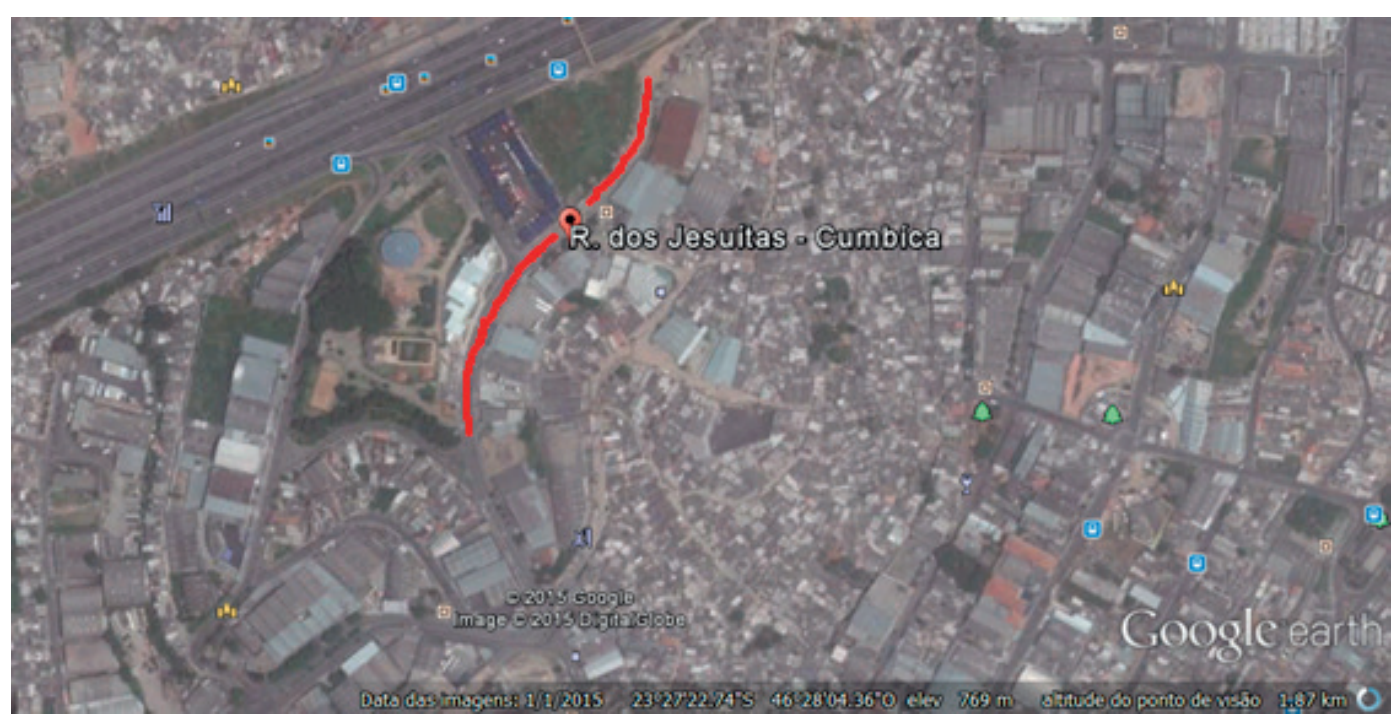

Fig. 1. Rua dos Jesuítas. Detalhe de configuração espacial antiga. Fonte: google earth. 


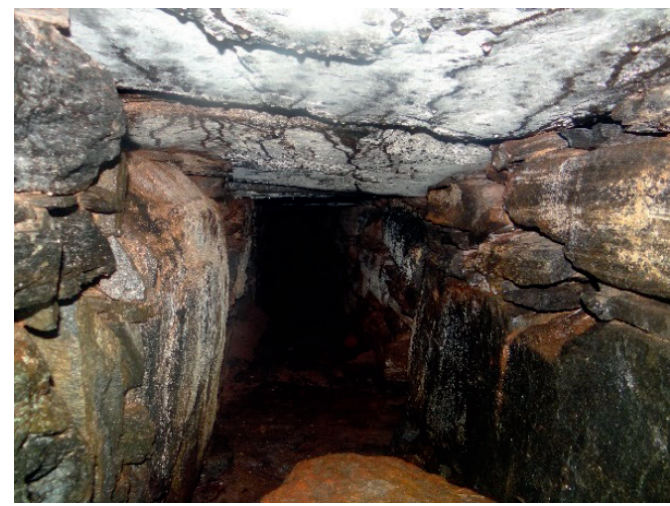

Fig. 2. Duto construído com pedras cortadas.

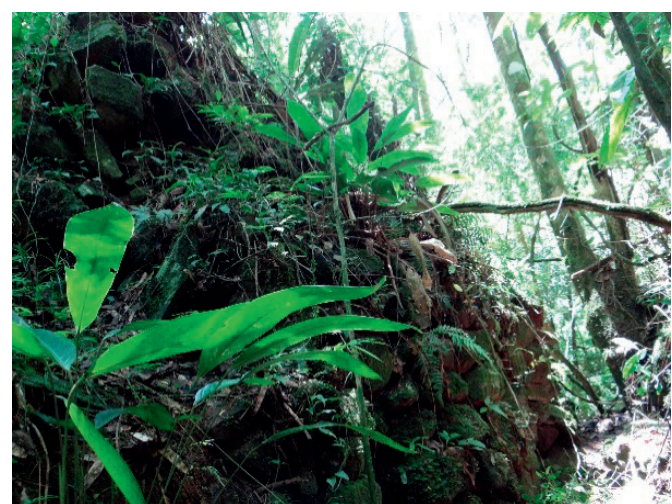

Fig. 3. Parede construída em pedras.

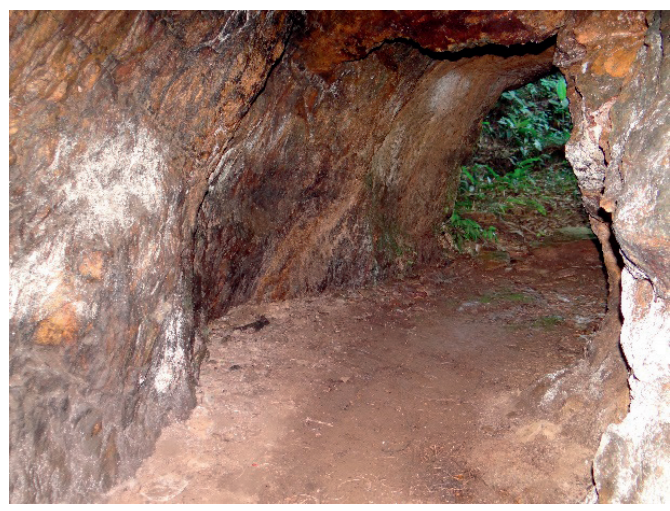

Fig. 4. Duto escavado em rocha.

pada pelos sítios 1, 2 e 3, há maior declividade e, portanto, maior pressão e energia da força d'água. Na área intermediária, representada pelos sítios 7 a 13, a declividade e a pressão no

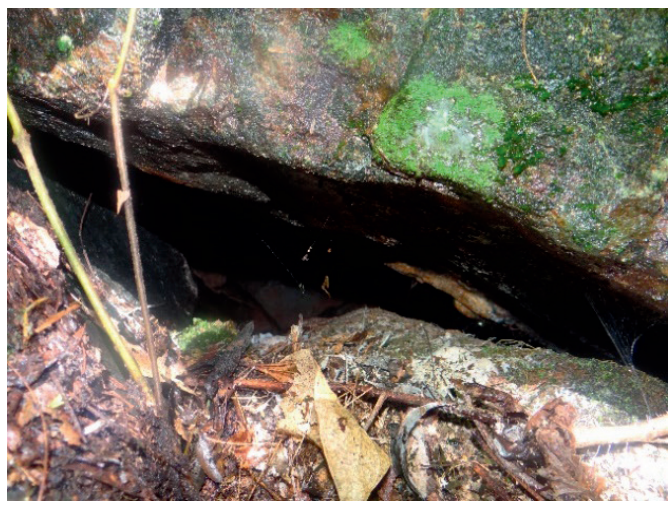

Fig. 5. Área de respiradouro de dutos d'água.

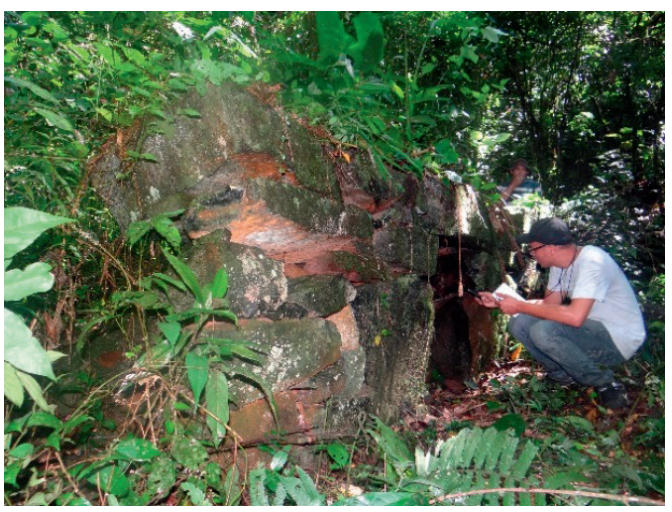

Fig. 6. Detalhe da Entrada de um duto.

escoamento dos cursos d'água é relativamente menor. Finalmente, onde hoje é localizada a gleba urbana, próximo ao bairro do Bonsucesso, chega-se a uma área de menor altitude, abaixo de 800 m, onde a pressão d'água é mais baixa.

A configuração espacial da área de dispersão das ruínas aponta uma estruturação que parte em linha do n. 1, seguindo pelas estruturas n. 2 e n. 3, até se radiarem em dois diferentes eixos a partir do n. 4 (sudoeste e sudeste), sendo que o ramo sudoeste é aquele que segue em direção à parte norte do Aeroporto, o sítio Tanque Grande ainda apresenta altitude elevada, e outro, o ramo sudeste, aquele que desemboca nas adjacências do Bonsucesso, ponto mais baixo.

As ruínas ligadas à mineração acompanham tanto a geologia local, os veios de ouro (fig. 8), quanto à hidrografia mais próxima dos veios de ouro (fig. 7). 
“Água mole em pedra dura, tanto bate até que fura": o caminho das águas na catalisação social no Brasil Colonial R. Museu Arq. Etn., 26: 95-114, 2016

\begin{tabular}{|c|c|c|c|c|c|}
\hline \multirow[t]{2}{*}{ No } & \multicolumn{3}{|c|}{ COORDENADAS (UTM) } & LOCALIDADE & \multirow[t]{2}{*}{ ALTITUDE (m) } \\
\hline & Zona & LESTE & NORTE & & \\
\hline 1 & $23 \mathrm{~K}$ & 354258,222 & 7421691,321 & \multirow{3}{*}{ Fazenda Colégio Progresso } & \multirow{3}{*}{$1000-1200$} \\
\hline 2 & $23 \mathrm{~K}$ & 354178,451 & 7421136,843 & & \\
\hline 3 & $23 \mathrm{~K}$ & 354187,241 & 7420244,868 & & \\
\hline 4.1 & $23 \mathrm{~K}$ & 353966,4 & 7419111 & \multirow{2}{*}{ Fazenda Soledade } & 926,76 \\
\hline 4.2 & $23 \mathrm{k}$ & 354014,6 & 7419023 & & 944,587 \\
\hline 5 & $23 \mathrm{~K}$ & 355022,1 & 7418541 & Fazenda Soledade & 913,692 \\
\hline 6 & $23 \mathrm{~K}$ & 354545,047 & 7418525,789 & Barragem -Lagoa de Pedra & 876,013 \\
\hline 7 & $23 \mathrm{~K}$ & 355569,625 & 7418320,510 & \multirow{2}{*}{ Fazenda dos Franco } & \multirow{2}{*}{$800-900$} \\
\hline 8 & $23 \mathrm{~K}$ & 355801,339 & 7417861,363 & & \\
\hline 9 & $23 \mathrm{~K}$ & 355665,203 & 7417347,648 & Dois Tanques/Lavras do Monjolo & 921,758 \\
\hline 10 & $23 \mathrm{~K}$ & 354077,875 & 7417659,402 & Ribeirão das Lavras & 849,45 \\
\hline 11 & $23 \mathrm{~K}$ & 356785,747 & 7415933,021 & Guaraçau & $800-900$ \\
\hline 12 & $23 \mathrm{~K}$ & 350949,223 & 7414228,547 & Tanque Grande & 828,602 \\
\hline 13 & $23 \mathrm{~K}$ & 353262,725 & 7413222,221 & Lavras do Fortaleza & 815 \\
\hline 14 & $23 \mathrm{~K}$ & 353533,816 & 7411877,504 & Lavras do Seminário & 787,707 \\
\hline 15 & $23 \mathrm{~K}$ & 353961,016 & 7410819,746 & Lavras do Jd Hanna & 763,917 \\
\hline
\end{tabular}

Tabela 2: Localização das estruturas de mineração de Guarulhos. Fontes: Plens 2015 e Pérez-Aguilar et alii, 2012 e Pérez-Aguilar et alii, 2013.

\section{Rios e caminhos: imbricamentos e conexões}

Os rios foram as primeiras grandes vias que possibilitaram grupos indígenas e colonizadores de entrarem mata adentro da atual área do município de Guarulhos. $\mathrm{O}$ acesso dos europeus em terras do atual município de Guarulhos ocorreu por meio do rio Tietê e rio Baquirivu.

Contudo, é possível entender, por meio da modificação paisagística, que o empreendimento minerador em Guarulhos seguiu ordem inversa daquela percorrida pelo colonizador europeu rumo ao norte, quando do primeiro contato com as sociedades locais. Os primeiros sítios parecem ter surgido na região norte e com maior altitude e depois descido para o sul. Além desses pontos, o sítio Tanque Grande também é mencionado em dados históricos, mostrando que nesse ponto um outro núcleo de mineração antigo.

As áreas próximas aos sítios 1,2 e 3 e o Tanque Grande se apresentam em uma topografia de alta declividade, tornando difícil o assentamento de grande número de pessoas. Já na área intermediária, onde as ruínas se bifurcam em direção sudeste e sudoeste, existem condições mais favoráveis para o assentamento de maior número de pessoas.

Podemos notar que entre os sítios localizados há uma maior concentração em áreas de declividade moderadas, estando, nessa categoria, inclusive, a atual igreja do Bonsucesso. Provavelmente, a escolha para assentamento mais duradouro em áreas de declividade moderada ocorra por conta dos problemas topográficos das áreas extremas e de alagamentos das áreas plainas. Se do ponto de vista topográfico as áreas mais ao norte apresentam cadeias de montanhas íngremes que dificultam a permanência de um grande número de pessoas, do ponto de vista das águas nas áreas baixas, tanto a pluviosidade quanto as centenas de cursos d'água alagavam grandes áreas e comprometiam o deslocamento das pessoas por trilhas e caminhos.

3 Durante a vigência do projeto PIPAG, dois artigos acerca da localização das minas de ouro foram publicados por PérezAguilar et alii, 2012 e Pérez-Aguilar et alii, 2013. Vale ressaltar que anteriormente uma primeira pesquisa já abordava as minas de ouro de Guarulhos: Juliani, C. et al, 1995.

1 Disponivel em: http://www.arqueologia.sites.unifesp.br/site 

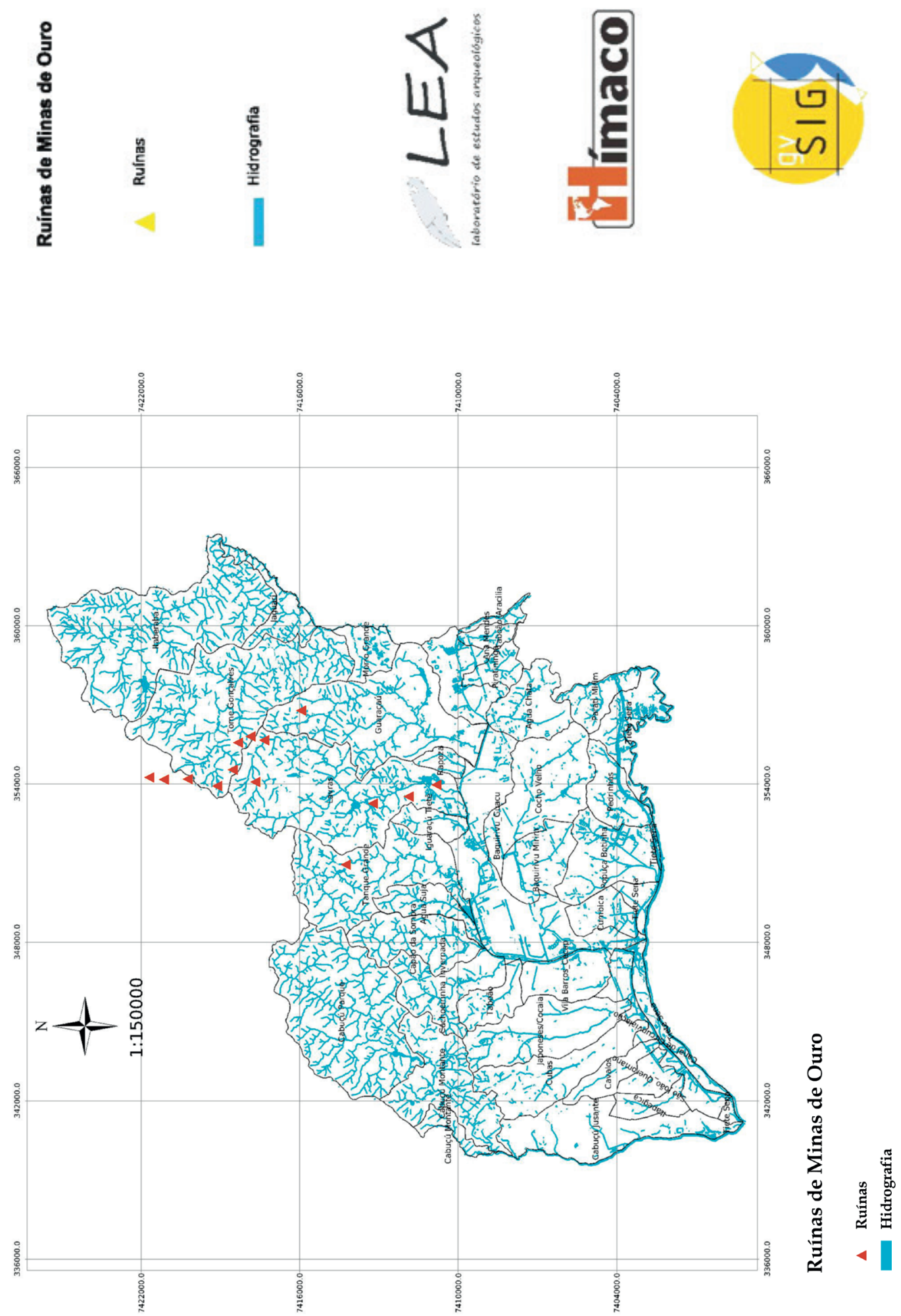

Fig. 7. Mapa de distribuição de ruínas de mineração. 
“Água mole em pedra dura, tanto bate até que fura": o caminho das águas na catalisação social no Brasil Colonial

R. Museu Arq. Etn., 26: 95-114, 2016

Dados históricos (Relatório PIPAG, 2015ㄴ) corroboram com a questão de terras inundáveis, as condições de intempéries prejudicavam o deslocamento de bens e de pessoas ainda no século XIX, fazendo com que apenas a partir desse período, quando do crescimento urbano do município de Guarulhos, maiores providências e empenho político para a abertura de novos caminhos e aterros contornassem problemas antigos de movimentação da população local.

De modo geral, as ruínas representam dutos, respiradouros, paredes de contenção dos morros e antigas trilhas para a mobilidade humana. Trata-se de pequenas trilhas em meio à mata que dão acesso às ruínas até os dias atuais. Essas pequenas trilhas levam, consequentemente, a caminhos maiores que interligam a outros canais e dutos. Os caminhos maiores levam a estradas antigas, mas ainda em uso na atualidade, tal como a estrada de Nazaré Paulista.

Necessariamente, as trilhas são percorridas em um curto período de tempo, a pé, enquanto que os caminhos e as estradas de terra demandavam mais tempo, energia e logística para o des-

\begin{tabular}{|c|c|c|}
\hline Nível & Casos & $\begin{array}{c}\text { Altitude } \\
\text { metros }\end{array}$ \\
\hline Extremo & $1,2,3,5,9$ & $1200-1000$ \\
\hline Moderado & $6,7,8,11,12,13$ & $999-800$ \\
\hline Baixo & 14,15 & $799-700$ \\
\hline
\end{tabular}

Tabela 3: Localização das ruínas de mineração em relação à topografia, de acordo com Earle (2006).

locamento de pessoas e podiam ser percorridos tanto a pé quanto a cavalo. Assim como os caminhos e estradas, os caminhos fluviais demandam mais tempo e energia e organização logística para cada viagem, necessitando ainda como meio de transporte formas de embarcações.

Grupos de menor densidade populacional necessitam maior espaço para locomoção para explotação do meio e subsistência, sendo o transporte a pé ou com tecnologias simples adaptada ao percurso de longa distância; enquanto que populações mais densas podem percorrer menores espaços em busca de sua subsistência (Earle, 2006: 262-3).
A partir da metodologia de movimentação e da implantação e utilização de caminhos é possível visualizar que apesar do alto grau de imbrincamento das trilhas de menor porte para acesso direto e pontuais das construções para o trabalho da mineração, como os dutos e canais, dentro da mata, os caminhos de conexão de longo percurso, apresentam-se em grande quantidade, articulando longos caminhos, estradas e rios.

Pelo mapeamento dos percursos, é possível identificar que as rotas de longa distância foram essenciais para a manutenção da vida cotidiana da sociedade colonial, sobretudo no que diz respeito aos eixos norte-sul, leste-oeste.

Parece haver três clusters de caminhos, o primeiro com mais caminhos antigos que seguem desde o Tietê rumo a Bonsucesso e segue para a estrada de Nazaré Paulista. O segundo, a partir da atual região central de Guarulhos, com menor densidade numérica de caminhos, que também levam à estrada de Nazaré Paulista e, o terceiro, na região oeste, região do Cabuçu, em posição intermediária em importância numérica, com estradas menores que cortam a região.

Ademais da paisagem, com seus caminhos e toda a rede de circulação, a alta quantidade de documentos históricos corroboram para a importância das rotas de longa distância serem essenciais na vida diária da população. Documentos apontam que ainda no século XIX, quando a importância do empreendimento da mineração já era exígua em relação a outras áreas de mineração do país e a outros empreendimentos econômicos do estado, as estradas de longo percurso continuam essenciais para a manutenção da vida da região e localidades adjacentes, como no exemplo a seguir (para mais informações ver Anexo 5 do Relatório PIPAG, Plens, 2015²):

\section{[p.013] Excelentíssimo Senhor \\ Acusando o recebimento do ofício de Vossa Excelência de 31 do mês findo em que me declara não poder aceitar a minha proposta para fazer os consertos da estrada geral que desta Freguesia segue à Vila de Nazaréth por menos de três contos de $\mathrm{r}$.}

2 Disponivel em: www.arqueologia.sites.unifesp.br/site 


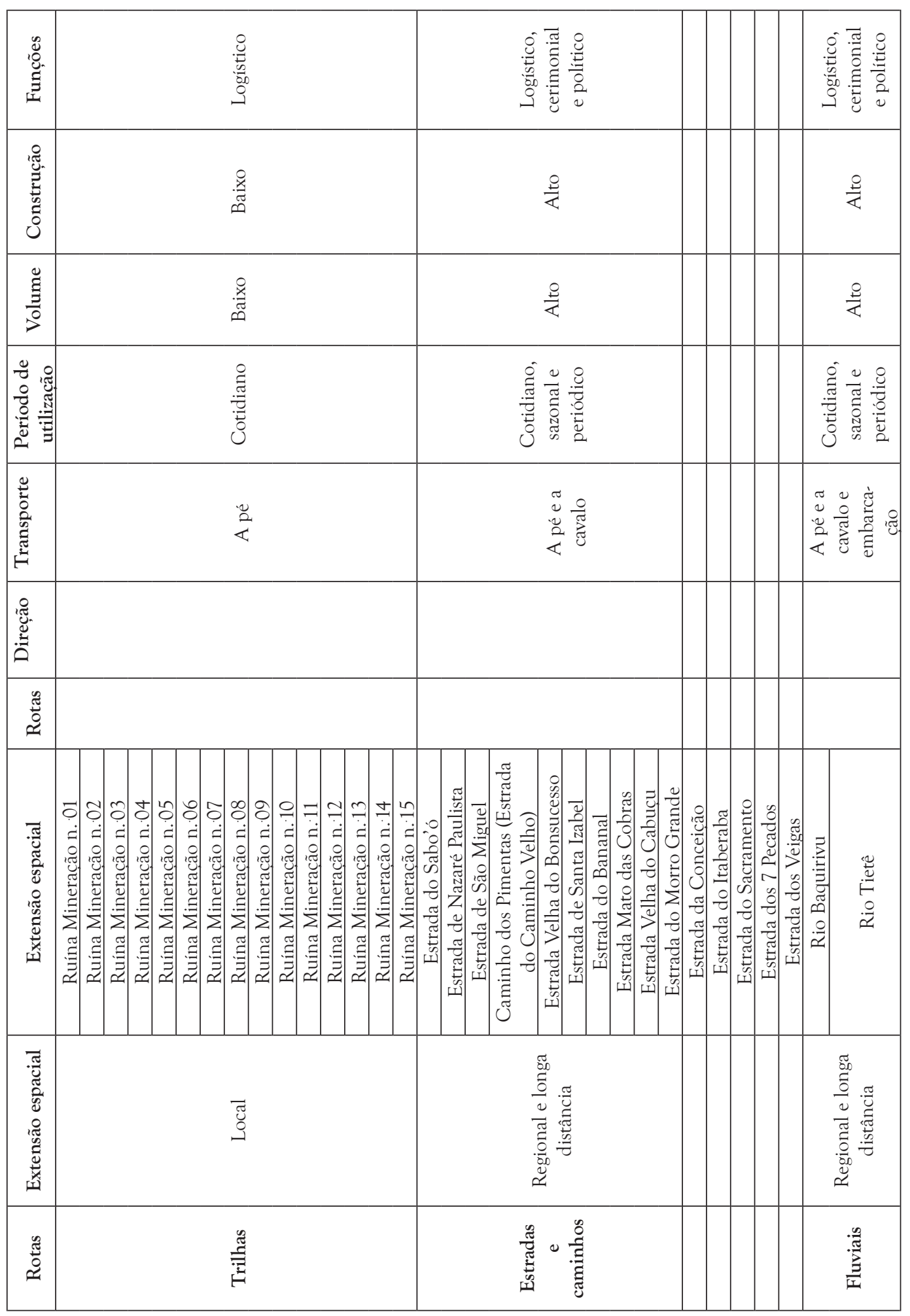

Tabela 4: Tipologia de rotas de movimentação adaptado de Earle (2006: 255). 
"Água mole em pedra dura, tanto bate até que fura": o caminho das águas na catalisação social no Brasil Colonial

R. Museu Arq. Etn., 26: 95-114, 2016

por que foram eles orçados visto que na Lei vigente do orçamento só foi consignado a quantia de um conto de r. para estas obras, tomei a resolução de tornar a oficiar a Vossa Excelência que com quanto esta quantia seja insuficiente convenho todavia de aplica-la em alguns dos consertos mais urgentes para evitar, que na força das águas fique cortado o trânsito desta estrada, por onde passam as tropas dos importantes Municípios de Nazareth e Sto. Antonio da Caxoeira (Cachoeira) que abastecem essa (?) Capital e o Porto de Santos de gêneros de $1^{a}$ necessidade.

Os consertos mais urgentes são os dos pontilhões sobre o aterrado do rio Baquiruvú-guassú sendo indispensável fazer-se de novo três pontilhões por estarem ameaçando (?) ruína os que existem, e um deles já abateu.

Junto remeto a Vossa Excelência o orçamento para estas obras.

Deus guarde a Vossa Excelência por muitos anos. Freguesia da Conceição dos Guarulhos 10 de novembro de 1864.

Até meados do século XIX, as propriedades de terras não eram autossuficientes, fazendo com que a população local necessitasse percorrer grandes distâncias para o trabalho, para a troca, compra e venda de produtos para a subsistência.

$O$ primeiro cluster antes mencionado, a região marcada pelos caminhos de São Miguel, Caminhos dos Pimentas, Caminho antigo do Bonsucesso e Nazaré Paulista, entrecortado por caminhos que se tornaram a Rodovia Dutra, engloba uma importante área para percurso de contingente humano e bens de consumo para outras áreas abastecedoras, como Santos, Minas Gerais, São Paulo e Rio de Janeiro.

Essa rede de caminhos composta por São Miguel, Caminhos dos Pimentas, Caminho antigo do Bonsucesso e Nazaré Paulista se articulam de modo a contornar as barreiras topográficas e hídricas, constituindo uma rede integrada de caminhos, levando à composição de uma região dependente entre si cotidianamente.

Para compreender os caminhos terrestres dessa conexão do período colonial na região mineradora, precisamos voltar à questão de São Miguel, tanto pelo Caminho de São Miguel ser uma histórica passagem dos grupos indígenas mas, sobretudo, pela evidência de que a toponímia São Miguel se trata justamente de uma grande região e não de um único lugar ou caminho. Dados apontam que o termo São Miguel se refere a uma área territorial muito mais abrangente do que tratado na atualidade, e não restrito à conhecida São Miguel Paulista, igreja do aldeamento jesuíta do século XVII, hoje localizada na zona leste do município de São Paulo, e próximo ao bairro dos Pimentas, em Guarulhos.

Ainda que dados históricos sobre a presença indígena após a colonização seja exígua, podemos partir da interpretação da paisagem e de dados históricos para entender sobre a presença indígena no território.

Como apontado por Monteiro (1998: 205-6), São Miguel se localizava dentro da área original de sesmaria concedida em 1580. A sesmaria intitulada Ururaí abrangia terras localizadas tanto do lado norte quanto sul do rio Tietê, sendo que na parte norte aglomeravam-se os colonos, enquanto que, ao sul, situava-se o núcleo do aldeamento que, por sua vez, tinha em suas adjacências áreas que integram parte do bairro de Caaguaçu (posteriormente se tornou freguesia de Guarulhos), as terras de Conceição e a área ao longo do rio Jaguari. Prova dessa territorialidade é que "(...) aparece na lista do donativo como o bairro de São Miguel (...) as pequenas propriedades ao redor da capela de Bonsucesso, a qual pertencia à fazenda de Francisco Cubas" (Monteiro, 1998: 204-6).

Obviamente que a concentração de grupos indígenas nessa área não era restrita ao aldeamento, sendo que o empreendimento aurífero dependia de uma mão de obra pesada e constante, tal como nos atestam a reconfiguração da paisagem e as ruínas identificadas. Os indígenas que trabalhavam na mineração de ouro certamente residiam nas proximidades da área de trabalho, não podendo se deslocar diariamente da área do aldeamento do lado sul do Tietê para a zona norte nas áreas de exploração de ouro.

Sobre os índios que residiam fora da área de aldeamento, ou mesmo sobre o empreen- 
dimento minerador no que tange à exploração, economia e modos de vida dos colonos, contamos com esparsas informações históricas. O que é de se esperar para o empreendimento minerador paulista que, como ressalta Vilardaga (2013), sempre esteve, convenientemente, em meio a uma "nuvem de fumaça".

A configuração dos territórios ocupados no período colonial ocorre pelas áreas de exploração dos recursos naturais, assim como pela instalação de bairros rurais de pequena produção de bens de consumo e capelas que atendiam e mantinham as populações indígenas.

O que aparece na lista de donativo como o bairro de São Miguel incluía, basicamente, as pequenas propriedades ao redor da Capela do Bonsucesso, a qual pertencia à fazenda de Francisco Cubas. Este, genro do grande sertanista Manuel Preto, havia herdado uma posse considerável de índios do seu sogro, agregando muitos outros através das atividades de apresamento de seu filho Francisco Cubas Preto, por sua vez um sertanista experimentado, participante de bandeira de 1666 e possuidor de cerca de duzentos índios quando da sua morte em 1673. Assim, o exemplo de Francisco Cubas demonstra, mais uma vez, a relação entre a fundação de capelas - e, por consequência, de bairros rurais - e a chegada de grandes levas de cativos (...) (Monteiro, 1998: 206).

No segundo quartel do século XVII, um grande número de indígenas está vinculado à Igreja do Bonsucesso. Contudo, vale lembrar que não se trata da mesma igreja implantada no atual bairro do Bonsucesso (que foi erigido em 1808), mas a originária, localizada provavelmente no eixo da atual Dutra, da qual não temos registros de sua localização exata. $\mathrm{O}$ importante aqui é se atentar ao fato de que os índios, a essa altura, estavam concentrados na região setentrional da sesmaria e não vinculados com o Aldeamento de São Miguel Paulista.

Embora diversos parentes de Francisco Cubas figurassem entre os principais residentes do bairro em 1679 - a viúva de Cubas Preto, constava como a maior contribuinte, com $4 \$ 000$-, ele rompe com alguns padrões de distribuição e transmissão de riqueza observadas em outros bairros. De fato, diferentemente de outras parentelas que se pulverizavam por meio do dote, procurou manter a propriedade e a família intactas. Chegando ao fim de sua vida, Cubas vinculou grande parte de sua riqueza e de seus índios a Capela do Bonsucesso. (Monteiro, 1998: 206).

Até esse período, aqueles que detinham o poder em relação às áreas de mineração de ouro na região de Guarulhos e sobre os indígenas, destacavam-se em relação ao poder econômico que, embora de valor elevado, não compartilhado com a sociedade local, mas concentrado nas mãos de uma única família, não produzia riqueza nem bem estar, nem social, e tampouco a si mesmos, necessitando, eles também, percorrer longos trajetos a fim de suprir suas necessidades.

No final do século XVII e todo o século XVIII, a região contava com apenas pequenas propriedades rurais (Relatório PIPAG, 2015, exemplos de propriedades em Mapa 2 nos Anexos 4), poucos produtores de trigo e criação de gado (Monteiro, 1998: 206), fazendo com que essa sociedade esparsa, nesse grande território, necessitasse de contatos em longa distância, passando a desenvolver sistemas sociais e redes de contatos bastante intensas para sua manutenção cotidiana.

É comum que entre sistemas sociais que se mantêm por meio de contatos intensos para a subsistência se mantenha também por meio de cerimônias periódicas entre os núcleos de contato (Earle, 2006: 262-3). Nesse sentido, surgem os lugares sagrados, que atraem os grupos sociais e asseguram uma rede de reciprocidade ${ }^{4}$.

4 Reciprocidade é um conceito da sociologia forjado por Marcel Mauss em que as relações sociais são símbolos com significados, que implicam em considerações recíprocas, expectativas e estratégias. Para saber mais, ver MAUSS, Marcel. "Ensaio sobre a Dádiva”. In: Sociologia e Antropologia. São Paulo: EPU, 1974. 
“Água mole em pedra dura, tanto bate até que fura": o caminho das águas na catalisação social no Brasil Colonial R. Museu Arq. Etn., 26: 95-114, 2016

Dentro desse contexto no período colonial, nessa vasta região onde os caminhos terrestres e aquáticos ajudam a população local a percorrer longos trajetos, há antigas capelas que atendem a população rural. Mais exatamente dentre os lugares de interesses religiosos da área em questão se destaca um, a Igreja Nossa Senhora do Bonsucesso. Nessa igreja há indícios de uma festa que remonta o final do século XVIII.

Para a execução da Festa, uma complexa manifestação cultural, o pequeno comércio local é o pano de fundo que mantém sua viabilidade logística, mas ela é especialmente conhecida por atrair romeiros de terras distantes atraídos pelo seu caráter religioso, a Carpição, ato da celebração que, por meio dos poderes da terra local, leva à cura de enfermidades.

Com mais de dois séculos de história, a Festa de Nossa Senhora do Bonsucesso agrega traços de permanência de um calendário agrícola, comércio de produtos variados e a comunicação e vínculo de diferentes segmentos sociais. A Festa é uma invocação de negociação entre os diferentes grupos para a manutenção do sistema social dependente entre si economicamente.

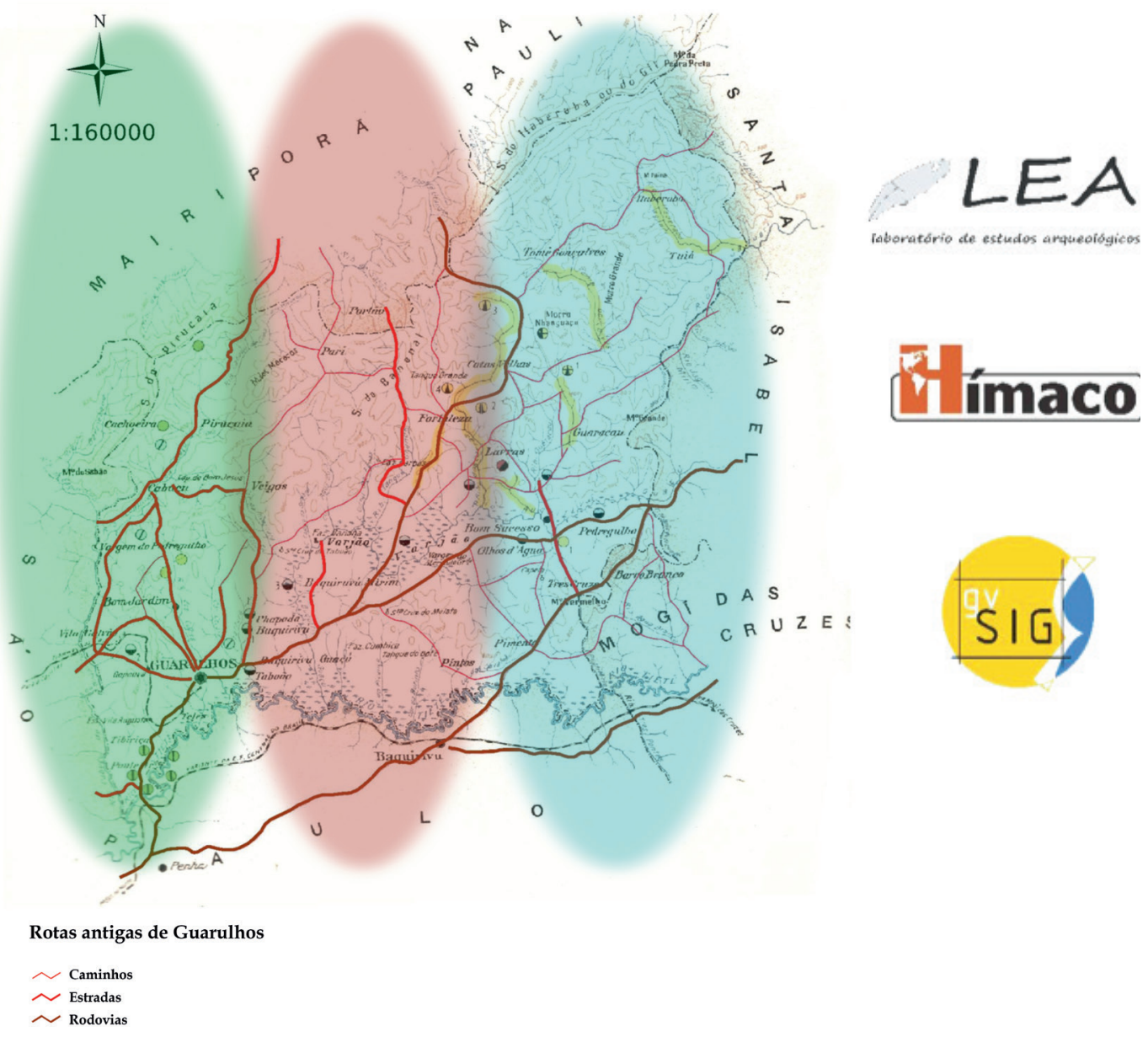

Fig. 8. Rotas antigas de Guarulhos. Adaptado de Instituto Geográfico e Geológico (1950: 105). 


\section{Água, ouro e sangue}

No caso da área de mineração de ouro dentre a qual está localizado o município de Guarulhos, é a água o elemento de vital importância que cintila através da história até os dias atuais, conferindo significado no espaço e para a sociedade desde o período colonial. A água possibilitou a movimentação de pessoas, a mineração de ouro, irrigação para plantações e sistema de escoamento de bens e o comércio.

$\mathrm{Na}$ área tratada nos documentos ora como São Miguel, de uma maneira abrangente referindo-se às terras doadas aos índios pela sesmaria de 1580 , e gradualmente usurpada por grileiros ao longo de mais de quatrocentos anos (ver Miranda) -, ora como áreas específicas como Lavras Velhas do Geraldo, Tanque Grande, entre outras toponímias, estabeleceuse o primeiro núcleo colonial de Guarulhos, configurado pelo uso e movimentação constante dos cursos d'água e os caminhos de terra que os margearam nessa região e ao redor do recurso aurífero.

Mas a formação desse primeiro núcleo colonial que teve como gatilho as fontes minerais e a presença indígena foi ainda mais complexa e, além dos fatores econômicos que levaram os colonizadores a se deterem na região, teve nos aspectos religiosos a concretização de um projeto colonizador, pois foi esse atrativo simbólico que selou e inculcou a importância do lugar entre a população local e seus visitantes.

Snead (2009: 44) lembra que a viagem por novos lugares e topografias é um processo de comprometimento entre pessoas e lugares, reafirmando compromissos. Nesse núcleo colonial, a água e o ouro foram responsáveis por conferir a sacralização da terra na parte setentrional dessa região da sesmaria de Ururaí, por meio do ato da Carpição da Festa do Bonsucesso, atraindo pessoas de diversas regiões ora para a festividade, ora como moradores que tomaram, pouco a pouco, as terras doadas aos indígenas.

Se a água foi o elemento que desde o período colonial estruturou o assentamento e sustentou diversos empreendimentos econômicos até os dias atuais em Guarulhos, em contrapartida o ouro conferiu uma riqueza simbólica, dado que a família de Cubas Preto, maior detentora do poder local, possuía recursos econômicos mas não usufruía de seus bens para o luxo, já que se encontravam em meio a uma população rural marginalizada pela pobreza, pela escravidão e o genocídio.

E, como diz o ditado "nem tudo que reluz é ouro" (Pearson, 1983), o empreendimento minerador em Guarulhos foi altamente impactante do ponto de vista social. Os grupos indígenas se desintegraram de seus laços familiares e sociais sendo reduzidos a aldeamentos e outras formas de escravização de seus corpos e almas, a tal ponto que já no século XIX sua total ausência na Vila é tida como indicativo de progresso.

Mas se o genocídio em massa e a miscigenação esporádica fizeram com que nomes e histórias indígenas desaparecessem dos documentos históricos e da memória social, sua presença se faz valer por todas as regiões de Guarulhos por meio das toponímias de rios, caminhos e lugares. Assim como a água que escorreu pelos rios, conferindo histórias de lugares, o sangue indígena permeou pela terra, cravando no espaço e no tempo a história de sua presença.

\section{Agradecimentos:}

Agradecimentos aos companheiros de campo Sr. Elton Soares de Oliveira, Evandro Souza, Gerônimo Luna Junior, Karin Shapazian e a Fapesp/Condephaat/SEC pelo financiamento do projeto.

PLENS, C.R.; PORTO, V.C. "Constant dripping wears away the stone": the path of waters in social catalysis in Colonial Brazil. R. Museu Arq. Etn., 26: 95-114, 2016. 
“Água mole em pedra dura, tanto bate até que fura": o caminho das águas na catalisação social no Brasil Colonial R. Museu Arq. Etn., 26: 95-114, 2016

\begin{abstract}
Guarulhos has many natural paths through hills, mountains, and a network of watersheds that allowed the Europeans to move around, enslave humans, and exploit local mineral resources. Besides the natural routes, Guarulhos (São Paulo, Brazil) gold mining archaeological remains (dated back to 1590 according to historical data) also show the great effort made by humans, especially indigenous people, for the construction of reservoirs and canals used for gold mining. Today's region of Guarulhos is important for understanding the earliest forms of contact during the Portuguese colonization. The region sheds light on the interaction between Portuguese and indigenous groups, as well as the Portuguese strategies for territorial expansion. The purpose of this article is to point out how the mining process has been shaping the behavior of Guarulhos's different segments of society since the beginning of this economic cycle to the present day.
\end{abstract}

Keywords: Archaeology of Colonialism; gold mining; indigenous slave labour; Archaeology of the Movement; Sacred Archaeology.

\title{
Referências Bibliográficas
}

Ab'Saber, A. 2007. Geomorfologia do sítio urbano de São Paulo. Edição fac-similar - 50 anos. Cotia - SP: Ateliê Editorial.

Alcock, S.E.; Cherry, J.F.; Davis, J.L. 1994. Intensive survey, agricultural practice and the landscape of Classical Greece. In: MORRIS, I. (Ed.). Classical Greece: Ancient Histories and Modern Archaeologies. Cambridge: Cambridge University Press: 137-70.

Alcock, S.E. 2002. Archaeologies of the Greek Past: Landscapes, Monuments, and Memories. The W. B. Stanford Memorial Lectures. Cambridge: Cambridge University Press.

Anschuetz, K.F.; Wilshusen, R. H.; Scheick, C. L. 2001. An Archaeology of Landscapes. Perspectives and directions. Journal of Archaeological Research, v. 9 (2): 157-211.

Beaudry, M.; Parno, T. (Eds.). 2013. Archaeologies of Mobility and Movement. New York: Springer. Feinman.

Bowser, B.J.; Zedeño, M. N. 2009. The Archaeology of Meaningful Places. Salt Lake City: University of Utah Press.
Brown, L.A. 2004. Dangerous places and wild spaces: creating meaning with materials and space at contemporary Maya shrines on El Duende Mountain. Journal of Archaeological Method and Theory, 11(1): 31-58.

Carl, P. City as Image versus Topography of Praxis. 2000. Cambridge Archaeology Journal, 10 (2): 328-355.

Carmichael, D.L.; Hubert, B.R.; Schanche, A. (Eds.). 1994. Sacred Sites, Sacred Places. One World Archaeology, 23, London: Routledge.

Carroll, A.K.; Zedeño, M.; Stoffle, R.W. 2004. Landscapes of the ghost dance: a cartography of Numic ritual. Journal of Archaeological Method and Theory, 11(2): 127-156.

Crumley, C.L.; Marquardt, W.H. 1987. Regional Dynamics: Burgundian Landscapes in Historical Perspectives. San Diego - New York: Academic Press.

Deetz, J. 1990. Landscapes as cultural statements. In: Kelso, W.M.; Most, R. (Eds.). Earth Patterns: Essays in Landscape Archaeo- 
logy. Charlottesville and London: University Press of Virginia: 2-4.

Earle, T. 2006. Routes through the Landscape: A comparative Approach. In: Snead, J.E. et al. (Eds.). Landscapes of Movement. Trails, Paths, and Roads in Anthorpological Perspective. University of Pennsylvania Museum of Archaeology and Anthropology: 253-270.

Feld, S.; Basso, K.H. (Eds.). 1996. Senses of Place. Santa Fe, N. M. School of American Research Press.

Fischer, C.T.; Thurston, T.L. (Eds.). 1999. Special Section: Dynamic Landscapes and Socio-political Process: The Topography of Anthropogenic Environment in Global Persptive. Antiquity 73: 630-88.

Hirsch, E.; O'Hanlon, M. (Eds.). 1995. The Anthropology of Landscape. Oxford: Oxford University Press.

Instituto Geográfico e Geológico. 1950. Ocorrências Minerais do Estado de São Paulo. v. 1. Municípios de S. Paulo, Santana do Paraíba, Barueri, Franco da Rocha, Guarulhos, Mogi das Cruzes, Suzano e Poá. Secretaria da Agricultura, São Paulo: 105.

Jordan, K. 2009. Colonies, Colonialism and Cultural Entaglement: The Archaeology of Past-Columbian Intercultural Relations. In: Majewski, T.; Gaimster, D. (Eds.). International Handbook of Historical Archaeology. New York: Springer: 31-49.

Juliani, C.; Beljavskis, P.; Juliani, L.J.C.O. 1995. "As mineralizações de ouro de Guarulhos e os métodos de sua lavra no período colonial." Geologia Ciência - Técnica, 13: 8-25.

Knapp, A.B.; Ashmore, W. 1999. Archaeological landscapes: Constructed, conceptualized, ideational. In: Ashmore, W. and Knapp, A.B. (Eds.). Archaeologies of Landscape: Contemporary Perspectives. Blackwell Publishers, Malden, MA: 1-30.
Kormikiari, M.C.N. 2014. Arqueologia da Paisagem. Laboratório de Estudos da Cidade Antiga do Museu de Arqueologia e Etnologia da Universidade de São Paulo. Disponível em https:// labeca.mae.usp.br. Acesso em: jan./fev. 2015.

Layton, R.; Ucko, P. (Eds.). 1999. The Archaeology and Anthropology of Landscape. Shaping our Landscape. London: Routledge.

Marcolin, R. 2013. A arqueologia da paisagem como instrumento de conhecimento do território. Disponível em http://www.citcem.org/. Acesso em: fev. 2015.

Monteiro, J.M. 1998. Negros da terra. Índios e bandeirantes nas origens de São Paulo. São Paulo: Companhia das Letras.

Orejas, A. 1991. Arqueología del paisaje: história, problemas e perspectivas. Archivo español de arqueología, 64 (163/164): 191-230.

Pearson, M. 1983. "All that glisters...”: assessing the heritage significance of mining places. Australian Historical Archaeology, 13: 3-10.

Pearson, M.; McGowan, B. 2000. Mining Heritage Places Assessment Manual. National Trust and the Australian Heritage Comission, Canberra.

Pérez- Aguilar, A.; Juliani, C.; Barros, E. 2012. Reconstituição do sistema de transporte de água associado à lavra de ouro durante o período colonial nos arredores de Guarulhos, SP, Brasil. Revista do Instituto Geológico, São Paulo, 33 (1): 1-22.

Pérez-Aguilar, A.; Juliani, C.; Barros, E.; Andrade, M.R.M.; Oliveira, E.S.; Braga, D.; Santos, R.O. 2013. Archaeological Gold Mining Structures from Colonial Period Present in Guarulhos and Mairiporã, Sao Paulo State, Brazil. Geoheritage, V. 5: 87-105.

Plens, C.R. 2015 Projeto de Inventário e Pesquisa Arqueológica - PIPAG. Relatório Final. FAPESP/Condephaat/Sec. 
"Água mole em pedra dura, tanto bate até que fura": o caminho das águas na catalisação social no Brasil Colonial

Rapoport, A. 1978. Aspectos humanos de la forma urbana. Barcelona: GG.

Rapoport, A. 1982. The Meaning of Built Environment: a Non-verbal Communication Approach. University of Arizona Press.

Silliman, S. 2010. Indigenous traces in colonial spaces. Journal of Social Archaeology, v. 10 (1): 28-58.

Snead, J.E. 2009. Trails of Tradition: Moment, Meaning, and Place. In: SNEAD, J. E. et al. (Eds.). Landscapes of Movement. Trails, Paths, and Roads in Anthropological Perspective, University of Pennsylvania Museum of Archaeology and Anthropology: 42-60.

Stewart, P.J.; Strathern, A. 2003. Landscape, Memory and History: Anthropological Perspectives. London: Pluto Press.
Stewart, A.M.; Keith, D.; Scottie, J. 2004. Caribou crossings and cultural meanings: placing traditional knowledge and archaeology in context in an Inuit landscape. Journal of Archaeological Method and Theory, 11(2): 183-212.

Vilardaga, J.C. 2013. As controvertidas minas de São Paulo (1550-1650). In: Varia Historia, Belo Horizonte, v. 29 (51): 795-815.

Whitridge, P. 2004. Landscapes, houses, bodies, things: place and the archaeology of Inuit imaginaries. Journal of Archaeological Method and Theory, 11(2): 213-50.

Würst, L. 1991. Employees Must Be of Moral and Temperate Habits. Rural and urban elites ideologies. In: McGuire, R.; Paynter, R. (Eds.). The Archaeology of Inequality. London: Basil Blackwell: 125-149. 